This is a draft of a chapter that appears in Depth Psychology and Mysticism, T. Cattoi and D. Odorisio (eds.), London: Palgrave, ISBN 978-3-319-79-95

Citations should reference the published version.

\title{
Apophasis and Psychoanalysis
}

\section{David Henderson}

The debate about the nature of psychoanalytic knowledge has been a perennial theme in psychoanalytic writing. This includes discussions about the scientific status of psychoanalysis, the aims of analysis, the nature of interpretation, the relationship between fantasy and reality, and so on. The 'talking cure' places a premium on insight and putting things into words. "Where id was there ego shall be," said Freud (2001). A strong implication is that where ignorance was there knowledge shall be. This chapter focuses however not on psychoanalytic knowledge, but on psychoanalytic ignorance and the disciplined learned ignorance of the analyst, in Jung's depth psychology.

In the realm of practice, if not always in that of theory, psychotherapists are very preoccupied with not knowing. While it is not officially in the prospectus, an important element of any training in psychoanalytic psychotherapy is developing the capacity to bear long stretches of time when you do not know and cannot know what is happening in the session or in the analysis.

Grinburg (1969) observed that, "In spite of its tremendous impact on mankind, paradoxically enough, it has not yet been possible to place and classify psychoanalysis within any of the existing fields of knowledge"(517). Wilfred Bion (1988) argued that the focus of the psychoanalyst must be on "the unknown and unknowable" (27). Ricoeur (1970) associated psychoanalysis with the hermeneutics of suspicion. Karlson (2000) speculated that:

One of the reasons that psychoanalysis as a science struggles with difficult epistemological problems is that its subject matter - the unconscious - is constituted in terms of negativity. What other science investigates something which is defined by the 
This is a draft of a chapter that appears in Depth Psychology and Mysticism, T. Cattoi and D. Odorisio (eds.), London: Palgrave, ISBN 978-3-319-79-95

Citations should reference the published version.

prefix un-?! The only resembling discipline, in this sense, may be the so-called "negative theology," which claims that an understanding of God can only be reached by stating what God is not. (4)

These views contribute to an appreciation of the problematic of unknowing in psychoanalysis, pointing toward the conclusion that psychoanalysis is a contemporary site for apophasis.

Sells (1994) translates apophasis as 'unsaying.' He distinguishes between apophatic theory and apophatic discourse. Apophatic theory "affirms the ultimate ineffability of the transcendent" (3). Apophatic discourse consists of "writings in which unnameability is not only asserted but performed" (3). This echoes the distinction often employed in psychotherapy between psychic content and psychic process. Psychoanalysis is both a theory and a performance.

The varieties of apophasis have been classified in a number of ways. Milem (2007) identifies four types of apophasis under the headings: metaphysical, desire, experience, and renunciation. Rorem (2008) writes about progressive apophatic, complete apophatic, and incarnational apophatic. McGinn (2009) claims that apophasis can be subjective or objective there being three varieties of relative subjective apophasis. Franke (2007) speaks of the silent matrix of the unmanifest and inexpressible.

Pseudo-Dionysius (hereafter Dionysius) uses a range of concepts that carry what Sells' calls apophatic intensity, including: apophasis (unsaying, denial, negation), aphaeresis (abstraction), hoion (as it were, so to speak), hyper (above, beyond, super), exaireou (to be removed from, transcend), epekeina (transcendent, beyond), exaiphnes (sudden, suddenly), ekstasis (ecstasy, ecstatic), apeiron (infinite, unlimited), agnousia ( unknowing, unknowable, 
This is a draft of a chapter that appears in Depth Psychology and Mysticism, T. Cattoi and D. Odorisio (eds.), London: Palgrave, ISBN 978-3-319-79-95

Citations should reference the published version.

undetectable), henousis (unity, union) and theousis (deification, divinization). The point is that there simply is no such thing as the apophatic. Apophasis is not one but many - opening the door to many interpretive possibilities.

Psychoanalytic theory and practice are saturated with apophatic manoeuvres. The intuition of apophasis at work in each of the traditions of psychoanalysis (Freudian, Jungian, Kleinian, Lacanian, Existential, etc.) accounts for their family resemblance. We recognise the clinical style and theoretical formulations of the disparate schools of analysis as analysis precisely because of the apophatic element. This chapter uses Cusa's (1997) concept of the coincidence of opposites, Deleuze's (1987) theories of the Body Without Organs and becoming, and Derrida's (1992) notion of space to illuminate distinct features of apophasis in the work of C.G. Jung.

\section{Coincidence of Opposites}

The coincidence of opposites (coincidentia oppositorum) is one of the fundamental organising principles in Jung's thought. Key concepts such as the self, the god image, the collective unconscious, wholeness, and synchronicity are instances of the coincidence of opposites. In 1931, in his first use of the term, Jung (1981a) describes the practice of psychology as a kind of performance of the coincidence of opposites: "The modern psychologist occupies neither the one position nor the other, but finds himself between the two, dangerously committed to 'this as well as that'... it is no longer possible for the modern psychologist to take his stand exclusively on the physical aspect of reality once he has given the spiritual aspect its due" (352).

Here Jung is holding the physical and spiritual to be a coincidence of opposites and is arguing that a modern psychology must accommodate both. Coincidence here refers to 
This is a draft of a chapter that appears in Depth Psychology and Mysticism, T. Cattoi and D. Odorisio (eds.), London: Palgrave, ISBN 978-3-319-79-95

Citations should reference the published version.

simultaneity, not to chance or randomness. Two phenomena coincide when they occupy the same space, be it logical, imaginative or material space. Jung's lifelong preoccupation with the coincidence of opposites is a preoccupation with trying to understand the simultaneous appearance of apparently incompatible phenomena, events or situations. We are reminded here of Sells' (1994) description of apophatic discourse:

Classical Western apophasis shares three key features: (1) the metaphor of overflowing or 'emanation' which is often in creative tension with the language of intentional, demiurgic creation; (2) dis-ontological discursive effort to avoid reifying the transcendent as an 'entity' or 'being' or 'thing'; (3) a distinctive dialectic of transcendence and immanence in which the utterly transcendent is revealed as the utterly immanent. (6)

Sells seems to be describing three instances of the coincidence of opposites:

overflowing/intentional (emanation/creation), dis-ontological/reifying, and transcendence/immanence.

Jung (1976) cites Nicholas of Cusa (1401-1464) as his source for the term. He asserts that the often "tortuous language" associated with the discussion of the union of opposites "cannot be called abstruse since it has universal validity, from the tao of Lao-tzu to the coincidentia oppositorum of Cusanus" (166). Along with the infinite disproportion between the finite and the infinite, and learned ignorance, the coincidence of opposites is one of the three central doctrines of Cusa's thought. Ideas of the coincidence of opposites predate Cusa, but he is the first to develop the concept systematically and to make it a lynchpin of his philosophy and theology. For Cusa the coincidence of opposites is a methodology. As Bond (1997) describes it:

At infinity thoroughgoing coincidence occurs... at true infinity there is one only and all are one. The coincidence of opposites provides a method that resolves contradictions without violating the integrity of the contrary elements and without diminishing the reality or the force of their contradiction. It is not a question of seeing unity where there is no real contrariety, nor is it a question of forcing harmony by synthesizing resistant 
This is a draft of a chapter that appears in Depth Psychology and Mysticism, T. Cattoi and D. Odorisio (eds.), London: Palgrave, ISBN 978-3-319-79-95

Citations should reference the published version.

parties. Coincidence as a method issues from coincidence as a fact or condition of opposition that is resolved in and by infinity. (22)

In Cusa's (1440) On Learned Ignorance the coincidence of opposites is described as one type of union of opposites. It is a "unity in convergence, that is, a 'falling together' ... a unity geometrically conceived, but without quantity... It is a unity of substance without mingling and without obliteration of either party or substance" (Bond 1997, 28). The coincidence of opposites is beyond the reach of discursive reasoning. The coincidence of opposites is a "unity to which neither otherness nor plurality nor multiplicity is opposed" (Bond 1997, 28).

According to Bond (1997), Cusa (1453) describes the coincidence of opposites as the wall of paradise, beyond which is God:

God is beyond the realm of contradictories... there exists an impenetrable barrier to human vision and reason... he intends that the reader understand not so much that God is the coincidence of opposites, but rather that opposites coincide in God... the notion of opposites coinciding requires a transcendent vision - seeing beyond particularity and sensibility, a seeing through and beyond the image or symbol, and an antecedent seeing, considering problems in their infinitely simple principle prior to contradiction. (46)

The coincidence of opposites is incomprehensible to human rationality. The encounter with the incomprehensible has a transforming effect on the identity of the searcher.

To see coincidence is still not to see God. God, the object of human's effort to see, however, acts on our seeing as subject so that the searcher and observer discovers oneself searched out, observed, measured, defined. This is one of the more interesting features of Cusa's treatise - the human as figura, the theologian discovering oneself as symbol; the searcher after the meaning behind symbols becomes oneself a symbol. (Bond 1997, 46-7)

The idea that "the searcher after meaning behind symbols becomes oneself a symbol," resonates with Jung's (1963) observations at the end of Memories, Dreams, Reflections: 
This is a draft of a chapter that appears in Depth Psychology and Mysticism, T. Cattoi and D. Odorisio (eds.), London: Palgrave, ISBN 978-3-319-79-95

Citations should reference the published version.

When Lao-tzu says: "All are clear, I alone am clouded," he is expressing what I now feel in advanced old age... there is so much that fills me: plants, animals, clouds, day and night, and the eternal in man. The more uncertain I have felt about myself, the more there has grown up in me a feeling of kinship with all things. In fact it seems to me as if that alienation which so long separated me from the world has become transferred into my own inner world, and has revealed to me an unexpected unfamiliarity with myself. (359)

There are some parallels between Jung's late reflections and Cusa's (1464) last work. Earlier, in 1460 Cusa had used the term possest to name God. As Bond (1997) explains, it is "a play on words, a coincidence of posse ('can') and est ('is'), the Can, the Possibility that at the same time Is, the Can-Is, which only God can be" (58). In On the Summit of Contemplation Cusa calls God Posse Itself. According to Bond (1997), Cusa is "superseding not only negation and affirmation but also the coincidence of opposites" (59). This echoes Dionysius' schema of kataphasis, apophasis, ekstasis. Posse Itself is "that without which nothing whatsoever can be, or live, or understand... without posse nothing whatsoever can be or can have, can do or can undergo... if it were not presupposed, nothing whatever could be... In its power are necessarily contained those things that are as well as those that are not" (Cusa 1997, 294-6). Seeing that Posse Itself involves neither comprehension nor cognition, Cusa "embraces the negation of knowing and at the same time the affirmation of sight" (Bond 1997, 62). The mind's capacity to see Posse Itself lies in its own posse. In this sense the posse of the mind is the image of God, Posse Itself:

This posse of the mind to see beyond all comprehensible faculty and power is the mind's supreme posse. In it Posse Itself manifests itself maximally, and the mind's supreme posse is not brought to its limit this side of Posse Itself. For the posse to see is directed only to Posse Itself so that the mind can foresee that toward which it tends, just as a traveller foresees one's journey's end so that one can direct one's steps toward the desired goal... For Posse Itself, when it will appear in the glory of majesty, is alone able to satisfy the mind's longing. For it is that what which is sought. (Cusa 1997, 297-8) 
This is a draft of a chapter that appears in Depth Psychology and Mysticism, T. Cattoi and D. Odorisio (eds.), London: Palgrave, ISBN 978-3-319-79-95

Citations should reference the published version.

Jung and Cusa share a view that there is a bridge between the human and a greater reality. For Jung this bridge is the self and for Cusa it is the posse of the mind. Jung and Cusa are espousing a negative anthropology that resonates with that of Marion's (2005) when he states "only the infinite and incomprehensible can comprehend man, and thus tell him of and show him to himself" (18).

\section{Deleuze}

The uncanny experience of being reminded of Jung when reading Deleuze is expressed by Zizek (2004) in characteristically pithy fashion: "No wonder, then, that an admiration of Jung is Deleuze's corpse in the closet; the fact that Deleuze borrowed a key term (rhizome) from Jung is not a mere insignificant accident - rather, it points toward a deeper link" (662). ${ }^{1}$ Hallward (2010) observes, "If there is an analogue within the psychoanalytic tradition to Deleuze's conception of the cosmos-brain it is not Lacan's unconscious, but Jung's cosmic consciousness" (48).

Davis (2001) links Deleuze explicitly with the tradition of negative theology, but in general little has been made of this kind of connection. It is possible to understand two of Deleuze's key concepts - "Body without Organs" (BwO) and "becoming” - as carriers of apophatic intensity. According to de Gaynesford (2001), "the BwO is defined apophatically, in relation to that which it is not. The same tendency informs the attempts by various theologians to define Christ's incarnation" (93).

The BwO stands in relation to organism. An organism exists as such because its shape has been externally imposed by God or another powerful agency. "We come to the gradual realization that the $\mathrm{BwO}$ is not at all the opposite of the organs. The organs are not its enemies. 
This is a draft of a chapter that appears in Depth Psychology and Mysticism, T. Cattoi and D. Odorisio (eds.), London: Palgrave, ISBN 978-3-319-79-95

Citations should reference the published version.

The enemy is the organism. The $\mathrm{BwO}$ is opposed not to the organs but that organization of the organs called the organism" (Deleuze and Guattari 1987, 176).

The BwO shares many characteristics of the collective unconscious. In Land's (2011) words, "The unconscious is not an aspirational unity but an operative swarm, a population of preindividual and prepersonal singularities, a pure dispersed and anarchic multiplicity, without unity or totality... This absence of primordial or privileged relations is the body without organs" (304). We might think of it as an archetypal maelstrom. Deleuze and Guattari (1987) assert that:

Where psychoanalysis says, "Stop, find your self again," we should say instead, "Let's go further still, we haven't found our BwO yet, we haven't sufficiently dismantled our self." Substitute forgetting for anamnesis, experimentation for interpretation. Find your body without organs. Find out how to make it. It's a question of life and death, youth and old age, sadness and joy. It is where everything is played out. (167)

There are some parallels between the dismantling of the organism to uncover or create the BwO and the process of analysis. Seem (1984) compared Deleuze's recommendation to make a BwO to Laing's encouragement to "mankind to take a journey, the journey through ego-loss" (xix). Jung (1976) observed that, "The self, in its efforts at self-realization, reaches out beyond the ego-personality on all sides; because of its all-encompassing nature it is brighter and darker than the ego, and accordingly confronts it with problems which it would like to avoid... For this reason the experience of the self is always a defeat for the ego" (545-6).

The creation of the $\mathrm{BwO}$ is a practice of unknowing which opens the practitioner to more unrestricted flows of life. Apophatic discourse can move in the direction of origins or in the direction of the future. The emphasis can be on an unknowable beginning or on an unknowable destination. The BwO could be seen as an example of a return to an incomprehensible origin. Becoming, a key concept in Deleuze's work, is concerned to create and accomplish an 
This is a draft of a chapter that appears in Depth Psychology and Mysticism, T. Cattoi and D. Odorisio (eds.), London: Palgrave, ISBN 978-3-319-79-95

Citations should reference the published version.

incomprehensible destiny: "Deleuze's pragmatic and future-oriented epistemology is oriented toward the creation of concepts 'for unknown lands,' as well as meanings and values 'that are yet to come"” (Smetsky and Delpech-Ramey 2010, 7).

The parallels with Jung's concepts of individuation and the transcendent function are immediately evident:

Becoming is a rhizome, not a classificatory or genealogical tree. Becoming is certainly not imitating, or identifying with something; neither is it regressing-progressing; neither is it corresponding, establishing corresponding relations; neither is it producing, producing a filiation or producing through filiation. Becoming is a verb with a consistency all its own; it does not reduce to, or lead back to, "appearing," "being," "equaling," or "producing." (Deleuze and Guattari 1987, 263)

Here becoming is being defined apophatically, by what it is not. Jung (1958) describes the necessity for the analyst to follow the lead of the patient; to not intervene with preconceived attitudes and assumptions in the unfolding of the patient's self-discovery or self-creation, "which sometimes drives him into complete isolation... It is, moreover, only in the state of complete abandonment and loneliness that we experience the helpful powers of our own natures" (342).

The patient is compelled to pursue a perilous course of action:

And though this desire opens the door to the most dangerous possibilities, we cannot help seeing it as a courageous enterprise and giving it some measure of sympathy. It is no reckless adventure, but an effort inspired by deep spiritual distress to bring meaning once more into life on the basis of fresh and unprejudiced experience. Caution has its place, no doubt, but we cannot refuse our support to a serious venture which challenges the whole of the personality. If we oppose it, we are trying to suppress what is best in man - his daring and his aspirations. And should we succeed, we should only have stood in the way of that invaluable experience which might have given a meaning to life. (Jung 1958, 342)

Deleuze (1995) echoes Jung's call to experience:

... one steps outside what's been thought before, once one ventures outside what's familiar and reassuring, once one has to invent new concepts for unknown lands, then methods and 
This is a draft of a chapter that appears in Depth Psychology and Mysticism, T. Cattoi and D. Odorisio (eds.), London: Palgrave, ISBN 978-3-319-79-95

Citations should reference the published version.

moral systems break down and thinking becomes... a "perilous act," a violence, whose first victim is oneself... Thinking is always experiencing, experimenting... and what we experience, experiment with, is... what's coming into being, what's new, what's taking shape. (103-4)

The transcendent function, which might be characterised as an apophatic method at the heart of Jung's work, like becoming, occurs in the between. It is not a repetition but a becoming-other than oneself. The transcendent function produces difference. Differentiation is the engine of individuation:

The subject-in-process, that is, as becoming, is always placed between two multiplicities, yet one term does not become the other; the becoming is something between the two, this something called by Deleuze a pure affect. Therefore becoming does not mean becoming the other, but becoming-other... The non-place-in-between acts as a gap, or differentiator, introducing an element of discontinuity in the otherwise continuous process of becoming and allowing the difference to actively intervene. (Semetsky 2006, 6)

The $\mathrm{BwO}$ and becoming operate as sites of apophasis within the work of Deleuze, who might be read as the philosopher for Jung's analytical psychology.

\section{Derrida}

In his essay, 'How to Avoid Speaking: Denials,' Derrida (1992) uses the theme of 'place' to organize his thoughts: "Figuration and the so-called places (topoi) of rhetoric constitute the very concern of apophatic procedures" (97). He does not present these as steps in a dialectic, because "we are involved in a thinking that is essentially alien to dialectic," (100) but as "paradigms" or "signs." He describes these paradigms in architectural terms as a mode that "will surround a resonant space of which nothing, almost nothing, will ever be said" (100). Jung's theory is often described in terms of architectonics. The theme of place has echoes of Jung's (1981d) discussion of mandalas. The mandala defines a space - psychic, imaginal, ritual - that

provides an orientation toward an ultimately unknowable content: "All that can be ascertained at 
This is a draft of a chapter that appears in Depth Psychology and Mysticism, T. Cattoi and D. Odorisio (eds.), London: Palgrave, ISBN 978-3-319-79-95

Citations should reference the published version.

present about the symbolism of the mandala is that it portrays an autonomous psychic fact... It seems to be a sort of atomic nucleus about whose innermost structure and ultimate meaning we know nothing" (183).

Derrida (1992) observes that the apophasis of Dionysius begins with prayer. Prayer functions as an orientation toward the unknown. The prayer at the beginning of the Mystical Theology is addressed simultaneously to God, to Dionysius' disciple Timothy and to the reader:

The identity of this place, and hence of this text, and of its reader, comes from the future of what is promised by the promise... the apophasis is brought into motion - it is initiated, in the sense of initiative and initiation - by the event of a revelation which is also a promise... the place that is thus revealed remains the place of waiting, awaiting the realization of the promise. Then it will take place fully. It will be fully a place. (Derrida 1992, 117-8)

This sense of the revelation that is full of promise can be seen in Jung's attitude toward psychic phenomena. The symbol contains promise of an as yet undisclosed meaning. Jung insisted on the importance of maintaining an open and expectant attitude toward the unconscious - waiting on the images. His texts can be read as addressed simultaneously to the unconscious and to the reader with an expectation of an unknown future.

Jung (1981b) recommends a similar attitude of alertness to the unknown in the case of dreams and of individuation. He reminds himself when he hears a dream, "I have no idea what this dream means" (283). "Even if one has great experience in these matters, one is again and again obliged, before each dream, to admit one's ignorance and renouncing all preconceived ideas, to prepare for something entirely unexpected" (287). The analyst by accepting his own ignorance is willing to be moved or illuminated by the dream. The dream provides perspective on the 
This is a draft of a chapter that appears in Depth Psychology and Mysticism, T. Cattoi and D. Odorisio (eds.), London: Palgrave, ISBN 978-3-319-79-95

Citations should reference the published version.

personal unconscious and life circumstances, but because personal complexes have roots in archetypal images, dreams are also windows into the collective unconscious.

In analysis Jung (1981c) finds that with some people there comes a time when they have exhausted an exploration of material that is dominated by repetition or family dynamics and the patient is challenged to discover their own individuality in a more radical way. In this situation the analyst must adopt a stance of absolute openness in relation to the patient's individuation:

A collective attitude enables the individual to fit into society without friction... But the patient's difficulty consists precisely in the fact that his individual problem cannot be fitted without friction into a collective norm; it requires a solution of an individual conflict if the whole of his personality is to remain viable. No rational solution can do justice to this task, and there is absolutely no collective norm that could replace an individual solution without loss. (Jung 1981c, 72-3)

Derrida's (1995) goal is to penetrate the impossible, rather than pointless repetition of a program. "Going where it is possible to go would not be a displacement or a decision, it would be the irresponsible unfolding of a program. The sole decision possible passes through the madness of the undecidable and the impossible: to go where it is impossible to go" (59).

The analytic space is a space set apart. The entrance and exit from the space receives a great deal of attention in psychoanalytic technique, as the integrity of the frame of analysis is considered vital in creating the possibility for the kind of openness that Jung is describing. Derrida (1992) asserts that in the work of Dionysius, "It is necessary to stand or step aside, to find the place proper to the experience of the secret" (89). He suggests that the practitioners of both deconstruction and negative theology appear suspect to outsiders because they seem to belong to secret societies: '“'Negative theologies' and everything that resembles a form of esoteric sociality have always been infortuitously associated with phenomena of secret society, as if 
This is a draft of a chapter that appears in Depth Psychology and Mysticism, T. Cattoi and D. Odorisio (eds.), London: Palgrave, ISBN 978-3-319-79-95

Citations should reference the published version.

access to the most rigorous apophatic discourse demanded the sharing of a 'secret'... It is as if divulgence imperilled a revelation promised to apophasis" (88). The stain of the secret, real or imagined, casts its aura over the analytic relationship and analytic institutions. The seal of confidentiality breeds both confidence and suspicion. In alchemy, as Jung (1981d) observes, "The substance that harbours the divine secret is everywhere, including the human body" (313).

According to Rayment-Pickard (2003), "Derrida argues that discourses of negation are always also affirmative, either echoing or presupposing the positivities they seek to describe by denials" (127). When he writes about the trace, it is possible to hear echoes with a possible interpretation of Jung's concept of archetype. "The most negative discourse, even beyond all nihilisms and negative dialectics, preserves the trace: The trace of an event older than it or of a 'taking-place' to come, the one and the other: there is here neither an alternative nor a contradiction" (Derrida 1992, 97). We could read this as a suggestion that one aspect of the apophatic dynamic at play between the ego and the archetype is that for the ego the archetype can represent simultaneously a trace of a primordial event and a trace of an unknown future. This is one way in which the archetype acts as a coincidence of opposites.

Bradley (2004) describes Derrida's method as a questioning of binary oppositions:

The binary differences that constitute Western metaphysics are shown to be preceded by a third position that belongs to neither and that allows those differences to appear as oppositional. This unthought space between the transcendental and the empirical is the aporia that - however impossibly - deconstruction attempts to think. (24)

This "unthought space" is the ground on which deconstruction meets the discourse of negative theology. This potential space between the transcendental and the empirical was also the space that Jung was exploring. His description of the work of the alchemists serves as a description of 
This is a draft of a chapter that appears in Depth Psychology and Mysticism, T. Cattoi and D. Odorisio (eds.), London: Palgrave, ISBN 978-3-319-79-95

Citations should reference the published version.

his own work. In it we can hear echoes of Derrida's (1992) discussion of negative theology, "It situates itself beyond all position" (91):

The imaginatio, as the alchemists understand it, is in truth a key that opens the door to the secret of the opus... The place or the medium of realization in neither mind nor matter, but that intermediate realm of subtle reality which can be adequately only expressed by the symbol. The symbol is neither abstract nor concrete, neither rational nor irrational, neither real nor unreal. It is always both. (Jung 1981d, 282-3)

Derrida and Jung are making and unmaking language in order to think about and imagine the space of individuation.

\section{Conclusion}

Psychoanalytic theory and practice are sites of apophatic theory and discourse. Jung's depth psychology is saturated with apophasis. The learned ignorance of the psychoanalyst, which is perfected and deepened over time, opens a space for the client to dwell in his or her subjectivity. The precarious unknowing of the analyst facilitates the emergence of the client's singularity, which paradoxically is their point of union with the infinite.

\section{References}

Bion, W.R. 1988. Attention \& Interpretation. London: Karnac

Bond, H. Lawrence. 1997. "Introduction." In Nicholas of Cusa: Selected Spiritual Writings, by Nicholas of Cusa, translated by H. Lawrence Bond. New York: Paulist.

Bradley, Arthur. 2004. Negative Theology and Modern French Philosophy. London: Routledge.

Cusa, Nicholas of. 1997. Nicholas of Cusa: Selected Spiritual Writings, translated by H. Lawrence Bond. New York: Paulist 
This is a draft of a chapter that appears in Depth Psychology and Mysticism, T. Cattoi and D. Odorisio (eds.), London: Palgrave, ISBN 978-3-319-79-95

Citations should reference the published version.

Davies, Oliver. 2001. "Thinking difference: A comparative study of Gilles Deleuze, Plotinus and Meister Eckhart." In Deleuze and Religion, edited by Mary Bryden. London: Routledge.

de Gaynesford, Maximilian. 2001. "Bodily organs and organisation." In Deleuze and Religion, edited by Mary Bryden. London: Routledge.

Deleuze, Gilles. 1995. Negotiations, 1972-1990, translated by Marin Joughin. New York: Columbia University Press

Deleuze, Gilles and Felix Guattari. 1987. A Thousand Plateaus: Capitalism and Schizophrenia. London: Continuum

Derrida, Jacques. 1992. "How to Avoid Speaking: Denial." In Derrida and Negative Theology, edited by H. Coward and T. Foshay. Albany, NY: SUNY Press.

Derrida, Jacques. 1995. On the Name. Stanford: Stanford University Press.

Franke, William. 2007. On What Cannot Be Said: Apophatic Discourses in Philosophy, Religion, Literature and the Arts, Volume I. Classic Formulations. Notre Dame, IN: Notre Dame University Press.

Freud, Sigmund. 2001. "New Introductory Lectures [1933]." In The Standard Edition of the Complete Psychological Works of Sigmund Freud, Vol. 22. London: Vintage

Grinberg, Leon. 1969. "New Ideas: Conflict and Evolution." The International Journal of Psychoanalysis 50: 517-528.

Hallward, Peter. 2010. "You Can't Have It Both Ways: Deleuze or Lacan." In Deleuze and Psychoanalysis: Philosophical Essays on Deleuze's Debate with Psychoanalysis, edited by Leen de Boole. Leuven: Leuven University Press.

Jung. C.G. 1958. "Psychotherapists or the clergy (1932)." In Psychology and Religion: West and East, Collected Works of C.G. Jung Vol. 11, translated by R.F.C. Hull. Princeton, NJ: Princeton University Press.

---. 1963. Memories, Dreams, Reflections, recorded and edited by Aniela Jaffe, translated by Richard and Clara Winston. New York: Vintage Books.

---. 1976. Mysterium Coniunctionis: An Inquiry into the Separation and Synthesis of Psychic Opposites in Alchemy, Collected Works of C.G. Jung Vol. 14, translated by R.F.C. Hull. Princeton, NJ: Princeton University Press. 
This is a draft of a chapter that appears in Depth Psychology and Mysticism, T. Cattoi and D. Odorisio (eds.), London: Palgrave, ISBN 978-3-319-79-95

Citations should reference the published version.

--- 1981a. "Basic Postulates of Analytical Psychology (1933)." In The Structure and Dynamics of the Psyche, Collected Works of C.G. Jung Vol. 8, translated by R.F.C. Hull. Princeton, NJ: Princeton University Press.

---. 1981b. "On the nature of dreams (1945)." In The Structure and Dynamics of the Psyche, Collected Works of C.G. Jung Vol. 8, translated by R.F.C. Hull. Princeton, NJ: Princeton University Press.

---. 1981c. "The Transcendent Function (1957)." In The Structure and Dynamics of the Psyche, Collected Works of C.G. Jung Vol. 8, translated by R.F.C. Hull. Princeton, NJ: Princeton University Press.

---. 1981d. Psychology and Alchemy, Collected Works of C.G. Jung Vol. 12, translated by R.F.C. Hull. London: Routledge.

Karlsson, Gunnar. 2000. "The Question of Truth Claims in Psychoanalysis." The Scandinavian Psychoanalytic Review, 23 (1): 3-24.

Land, Nick. 2011. Fanged Noumena: Collected Writings 1987-2007. Falmouth: Urbanomic

Marion, Jean-Luc. 2005. "Mihi magna quaestio factus sum: The Privilege of Unknowing." Journal of Religion 85(1)

McGinn, Bernard. 2009. "Three forms of Negativity in Christian Mysticism." In Knowing the Unknowable: Science and Religions on God and the Universe, edited by J. Bowker. London: Tauris

Milem, Bruce. 2007. "Four Theories of Negative Theology." Heythrop Journal 48

Rayment-Pickard, Hugh. 2003. Impossible God: Derrida's Theology. Aldershot, UK: Ashgate

Ricoeur, Paul. 1970. Freud and Philosophy: An Essay on Interpretation. New Haven: Yale

Rorem, Paul. 2008. "Negative Theologies and the Cross." Harvard Theological Review 101 (3-4)

Seem, Mark. 1984. "Introduction." In Anti-Oedipus: Capitalism and Schizophrenia by Gilles Deleuze and Felix Guattari. London: Continuum

Sells, Michael A. 1994. Mystical Languages of Unsaying. Chicago: University of Chicago Press.

Semetsky, Inna. 2006. Deleuze, Education and Becoming. Rotterdam: Sense Publishers. 
This is a draft of a chapter that appears in Depth Psychology and Mysticism, T. Cattoi and D. Odorisio (eds.), London: Palgrave, ISBN 978-3-319-79-95

Citations should reference the published version.

Semesky, Inna and J.F. Delpech-Ramey. 2010. "Jung's Psychology and Deleuze's Philosophy: The unconscious in learning." Educational Philosophy and Theory.

Zizek, Slavoj. 2004. "Notes on a Debate 'From Within the People."' Criticism 46(4). 